\title{
Zinc and Strontium Based Phosphate Glass Beads: A Novel Material for Bone Tissue Engineering
}

\author{
Mustafa AlQaysi ${ }^{1}$, Alaa Aldaadaa ${ }^{2}$, Nicky Mordan $^{1}$, Rishma Shah ${ }^{3}$, Jonathan C Knowles ${ }^{1,4}$
}

${ }^{1}$ Division of Biomaterial and Tissue Engineering, UCL Eastman Dental Institute, 256 Grays Inn Rd, London, UK, WC1X 8LD

${ }^{2}$ Division of Maxillofacial Medicine and Surgery, UCL Eastman Dental Institute, 256 Grays Inn Rd, London, UK, WC1X 8LD

${ }^{3}$ Department of Orthodontics, School of Dentistry, University of North Carolina, 385 S Columbia St, Chapel Hill, USA, NC 27599

${ }^{4}$ Department of Nanobiomedical Science and BK21 Plus NBM, Global Research Center for Regenerative Medicine, Dankook University, Cheonan, Republic of Korea, 518-10 Anseo-dong, Dongnam-gu, Cheonan, Chungcheongnam-do, South Korea 


\begin{abstract}
$\underline{\underline{\text { Abstract }}}$
Degradable phosphate-based glasses that contain strontium, zinc and calcium were investigated to examine its function as an osteoconductive material. Glass beads of the general formula of $\left(\mathrm{P}_{2} \mathrm{O}_{5}\right)-\left(\mathrm{Na}_{2} \mathrm{O}\right)-\left(\mathrm{TiO}_{2}\right)-(\mathrm{CaO})-(\mathrm{SrO})$ or $(\mathrm{ZnO})$ were prepared by melt quench technique followed by milling and spheroidisation. Glass bead size distribution was initially measured by SEM. Then, some of these samples were immersed in deionized water to evaluate both the surface changes and measure the ion release rate, whereas other glass beads samples were incubated in culture media to determine $\mathrm{pH}$ changes. Furthermore, human osteoblast-like osteosarcoma cells MG-63 and human mesenchymal stem cells were seeded on the glass beads to determine its cytocompatibility via applying CCK assay, ALP assay and Ca assay. SEM images and fluorescence images of confocal microscopy were performed for the cellular studies. While mass degradation and ion release results displayed a significant increase with zinc and strontium incorporation within time, $\mathrm{pH}$ results showed an initial increase in pH followed by a decrease. Cellular studies emphasised that all formulations enhanced cellular proliferation. Phosphate glass with zinc content $5 \mathrm{~mol} \%$ and strontium content of $17.5 \mathrm{~mol} \%,(\mathrm{ZnO} 5)$ and $\mathrm{SrO} 17.5$ respectively, displayed more promising results although they were insignificantly different from that of control $(p>0.05)$. This may suggest their applicability in hard tissue engineering.
\end{abstract}

Keyword: phosphate- based glass, zinc, strontium, calcium, biomaterial, tissue engineering, osteogenesis. 


\section{Introduction}

Nowadays the high rate of bone fractures, as a result of pathological bone diseases and trauma, necessitates an effort to create a new generation of biomaterials for bone tissue regeneration. In fact, there are various treatment options for bone defects, which vary from conservative therapy to radical orthopedic surgeries. The latter may require the use of bone grafts, mainly autogenous graft. This may associate with much morbidity such as blood loss, pain and sepsis. This pushed to develop other options of synthetic grafts to reduce such side effects (1). Phosphate-based glass is one of these synthetic options that studied as osteoconductive biomaterials for bone treatment application. This may be related to its degradable nature and ion releasing that may have a positive role not only on bone growth but also on bone cell responses (2). Various studies were carried out on different phosphate glass systems starting from the basic tertiary glass and ending in the complex glass structure. Studies on the former were limited only to the $\left(\mathrm{P}_{2} \mathrm{O}-\mathrm{CaO}-\mathrm{Na}_{2} \mathrm{O}\right)$ system and most of these were basically on glass discs, and these studies showed that calcium oxide incorporation can decrease glass degradation rate $(3,4)$. The more advanced glass systems $\left(\mathrm{P}_{2} \mathrm{O}_{5}-\mathrm{SiO}_{2}-\mathrm{CaO}-\right.$ $\mathrm{MgO}-\mathrm{Na} 2 \mathrm{O}-\mathrm{K}_{2} \mathrm{O}$ ) were investigated also where phosphate glass was produced in highly porous form scaffold that was resembling the cancellous bone. These scaffolds exhibited acceptable metabolic activity for hMSCs (5).Other attempts used different technique in the production of multi metal oxides $\left(\mathrm{P}_{2} \mathrm{O}-\mathrm{CaO}-\mathrm{Na}_{2} \mathrm{O}-\mathrm{K}_{2} \mathrm{O}\right)$ phosphate glass scaffold. These produced scaffolds believed to have both the biodegradation and bioactivity properties(6). However, all these varieties in glass composition may lead to different glass degradation rates. Hence further attempts were carried out to produce a glass composition with the optimum degradation rate. Multiple important studies were performed for achieving this purpose by adding titanium dioxide to glass composition; this resulted in lower degradation rates and better cytocompatibility $(7,8)$. The addition of various proportions of both zinc and strontium to the tertiary phosphate glass was also studied. It was found in previous study that compensating $(0-10 \mathrm{~mol} \%)$ of $\mathrm{CaO}$ with $\mathrm{ZnO}$ did not have any significant effect on mass loss in comparison with $>10 \mathrm{~mol} \%$ replacement of $\mathrm{CaO}$ of which it had a higher mass loss (9). As a result of this mass loss, zinc release was enhanced giving rise to a decrease in biocompatibility of these particular glasses (10). Other experiments aimed to determine the effect of inclusion of strontium in phosphate glasses taking into consideration that strontium has a wellknown role in bone tissue growth and bone density enhancement (11). One of these 
experiments investigated the physical and biological properties of different strontium silicate glasses $\left(\mathrm{SiO}_{2}\right)_{46.5}-\left(\mathrm{P}_{2} \mathrm{O}_{5}\right)_{1}-\left(\mathrm{Na}_{2} \mathrm{O}\right)_{26.4}-(\mathrm{CaO})_{(23.1-\mathrm{x})}-(\mathrm{SrO})_{\mathrm{x}}(\mathrm{x}=0,2.3,11.5$ or 23.1) (mol\%) and revealed that increasing strontium may improve cell proliferation and enhance the anabolic activity of alkaline phosphatase (ALP) in Saos-2 osteoblast like cells. This may be due to the fact that strontium has a dual action of preventing resorption of calcium phosphate by the osteoclasts cells and decreasing phosphatase protein activity (12). These results were further confirmed by the addition of strontium to borate-based glasses which enhanced both glass degradation and formation of an apatite layer encouraging Saos-2 osteoblast like cells to adhere to the glass surface (13). Another trial investigated the addition of strontium to phosphate based glass discs in different percentages $\left(\mathrm{P}_{2} \mathrm{O}_{5}\right)-\left(\mathrm{Na}_{2} \mathrm{O}\right)-(\mathrm{CaO})-(\mathrm{SrO})$ and found that strontium additives can lead to enhancement in degradation more than that of strontium free glass discs. It can also give a slightly positive outcome in regards to cell culture (14). Later on, other attempts were performed to investigate quaternary strontium phosphate glasses which involved the development of four different compositions $\left(\mathrm{P}_{2} \mathrm{O}\right)_{50}-\left(\mathrm{TiO}_{2}\right)_{3}-\left(\mathrm{Na}_{2} \mathrm{O}\right)_{17^{-}}$ $(\mathrm{CaO})_{(30-\mathrm{x})}-(\mathrm{SrO})_{\mathrm{x}}(\mathrm{x}=0,1,3,5)$ and showed that despite the rise of degradation rate as strontium oxide increased, cell proliferation of MG63 cells was not affected and showed no significant differences compared to $\mathrm{SrO} 0$ and $\mathrm{SrO} 5$ (15). Two recent studies examined four different compositions of both strontium and zinc based phosphate glasses and revealed that SrO17.5 and SrO35 were suitable for MG63 cells growth, whereas $\mathrm{ZnO} 15$ showed a degree of cytotoxicity in comparison to both $\mathrm{ZnO} 5$ and $\mathrm{ZnO10}$ as both of them exhibited acceptable results of biocompatibility and metabolic activity $(16,17)$. Although these have shown some cellular promising results of adding zinc and strontium to phosphate glass, they were only performed on glass discs, as a primary step toward creating scaffolds, as they did not have the full requirements of a scaffold. The main aim of this study was to develop glass in a more useful format i.e. glass beads, of previous compositions that had clinical potential in addition to further assessment of these compositions aiming to apply phosphate glasses in clinical related bone repair treatment. 


\section{Materials and methods}

\section{Glass preparation}

Four different compositions of phosphate glass beads were developed to check their cellular biocompatibility and the ability of cells to both penetrate through and adhere to them. This was performed using the following precursors: phosphorus pentoxide $\left(\mathrm{P}_{2} \mathrm{O}_{5} 98 \%\right.$, VWR, Lutterworth, UK), sodium dihydrogen phosphate $\left(\mathrm{NaH}_{2} \mathrm{PO}_{4}, 99 \%\right.$, VWR), titanium dioxide $\left(\mathrm{TiO}_{2}, 99 \%\right.$, VWR $)$, calcium carbonate $\left(\mathrm{CaCO}_{3}, 98.5 \%\right.$, VWR), strontium carbonate $\left(\mathrm{SrCO}_{3}, 99.9 \%\right.$ Sigma-Aldrich Gillingham, UK) and zinc oxide ( $\mathrm{ZnO}$, 99.95\%, Sigma-Aldrich Gillingham, UK). The glass compositions were spitted into zinc and strontium groups. While zinc group was $50 \mathrm{P}_{2} \mathrm{O}_{5}-10 \mathrm{Na}_{2} \mathrm{O}-5 \mathrm{TiO}_{2}$ - (35-x) $\mathrm{CaO}-\mathrm{x} \mathrm{ZnO}$ (mol \%) where $\mathrm{x}$ (zinc oxide) was 5\% mol and 10\% mol, strontium was $50 \mathrm{P}_{2} \mathrm{O}_{5}-10 \mathrm{Na}_{2} \mathrm{O}-5 \mathrm{TiO}_{2}-(35-\mathrm{x}) \mathrm{CaO}-\mathrm{x}$ where $\mathrm{x}$ (strontium oxide) was $17.5 \% \mathrm{~mol}$ and $35 \%$ mol. Electronic balance (Sartorius) was used for weighing precursors powder (Table 1) followed by blending using Stomacher 400 blender/Seward. Following mixing of the precursors, the mixture was then placed into a $200 \mathrm{ml}$ volume $\mathrm{Pt} / 10 \% \mathrm{Rh}$ crucible type 71040 (Johnson Matthey, Royston, UK) which was subsequently placed in a furnace (Carbolite) at $1350^{\circ} \mathrm{C}$ for four hours, then the melted glass was quenched on metal plate. The quenched glass was broken into small pieces then further milled by (MM 301 Mixer Mill, Retsch GmbH and Hope, UK). Afterwards, glass beads were produced by flame spheriodisation apparatus following the method performed previously by Lakhkar et al (8) and were collected in 4 different glass containers which were primarily visualised under light microscope to confirm their production.

phosphate glass composition

\begin{tabular}{|c|c|c|c|c|c|c|c|}
\hline \multicolumn{2}{|c|}{ Glass name and composition } & & \multicolumn{5}{|c|}{ Amount (grams) } \\
\hline & & $\mathrm{P}_{2} \mathrm{O}_{5}$ & $\mathrm{Na}_{2} \mathrm{O}$ & $\mathrm{TiO}_{2}$ & $\mathrm{CaO}$ & $\mathrm{Sr}$ & $\mathrm{ZnO}$ \\
\hline $\mathrm{SrO} 17.5 \%$ & $\mathrm{P}_{50} \mathrm{Na}_{10} \mathrm{Ti}_{5} \mathrm{Ca}_{17.5} \mathrm{Sr}_{17.5}$ & 56.8 & 24 & 4 & 17.5 & 25.8 & 0 \\
\hline $\mathrm{SrO} 35 \%$ & $\mathrm{P}_{50} \mathrm{Na}_{10} \mathrm{Ti}_{5} \mathrm{Sr} 35$ & 56.8 & 24 & 4 & 0 & 51.6 & 0 \\
\hline $\mathrm{ZnO} 10 \%$ & $\mathrm{P}_{50} \mathrm{Na}_{10} \mathrm{Ti}_{5} \mathrm{Ca}_{25} \mathrm{Zn}_{10}$ & 56.8 & 24 & 4 & 25 & 0 & 8.14 \\
\hline $\mathrm{ZnO} 15 \%$ & $\mathrm{P}_{50} \mathrm{Na}_{10} \mathrm{Ti}_{5} \mathrm{Ca}_{20} \mathrm{Zn}_{15}$ & 56.8 & 24 & 4 & 20 & 0 & 12.21 \\
\hline
\end{tabular}

Table 1: phosphate glass beads composition 


\section{XRD.}

The next step after glass preparation was evaluation of glass structure crystallinity by using X-ray diffractometer XRD (D8 Advance Diffractometer,Bruker, Coventry, UK) to ensure that our sample were not crystalised. Specimens of all glass powder were positioned in a flat plate geometry, and $\mathrm{Ni}$-filtered $\mathrm{Cu}$ Ka radiation was used. Data were collected using a Lynx Eye detector with a step size of $0.02^{\circ}$ over an angular range of $2 \theta=10-100^{\circ}$ and a count time of 12 seconds.

\section{Glass Beads distribution}

About $50 \mathrm{mg}$ was taken from each of the synthesized glass beads; this was distributed on sticky dark tabs which were placed on an SEM stub for particle size measurement. The powder was slightly blown by compressed air to ensure its retention on the dark tabs. Following this, coating with gold and visualization under scanning electron microscope (SEM) (Philips XL30 FEGSEM) was performed. Five SEM images were chosen from various sites from stub (center, left, right, up and down), the diameter size in microns for each bead was determined using Saturn software to measure the frequency distribution of the produced glass beads .

\section{Glass degradation}

Glass degradation study was performed by incubating $200 \mathrm{mg}$ of each composition of glass beads in $2 \mathrm{ml}$ of ultrapure $18 \mathrm{M} \Omega / \mathrm{cm}^{2}$ water at $37^{\circ} \mathrm{C}$ for (day $1,4,7,14$ ). About $50 \mathrm{mg}$ was taken out at each time interval to be visualized under SEM to assess the degradation and the surface changes.

\section{$\underline{\text { Ion release }}$}

Ion release study aimed to calculate the concentration of different ions as this might be helpful in understanding the link between ions concentration and the cellular response. This was done by using triplicates of $100 \mathrm{mg}$ of each glass beads composition; these triplicates were immersed in $1 \mathrm{ml}$ of ultrapure $18 \mathrm{M} \Omega / \mathrm{cm}^{2}$ water and incubated at $37^{\circ} \mathrm{C}$ for four time points (1, 4, 7 and 14 days). At each time point, the de ionized water was stored for ion release study and replaced with fresh for the next time point. Then ion analysis was carried out for the anions $\left(\mathrm{PO}_{4}{ }^{3-}, \mathrm{P}_{2} \mathrm{O}_{7}{ }^{4-}, \mathrm{P}_{3} \mathrm{O}_{9}{ }^{4-}, \mathrm{P}_{3} \mathrm{O}_{10}{ }^{5-}\right)$ and cations $\left(\mathrm{Na}^{+}, \mathrm{Ca}^{2+}, \mathrm{Zn}^{2+}, \mathrm{Sr}^{2+}\right)$ using the ion chromatography systems (ICS1000, ICS 2500, 
Dionex, Thermo Scientific, Hemel Hempstead, UK). For the cation measurements all the samples were filtered prior to measurement to remove the anions (OnGuard IIa, Dionex). The ions concentration was calculated at each time point and accumulated to the previous time point.

\section{pH study}

$\mathrm{pH}$ measurement was determined by using triplicates of $200 \mathrm{mg}$ glass beads in $2 \mathrm{ml}$ culture media in 24 well plates for (day 1, 4, 7, 14). The glass beads were incubated at $37^{\circ} \mathrm{C}$ for the whole time period and changed every two days to mimic the cell culture study environment. At each point, the culture media $\mathrm{pH}$ was measured with an Orion star A111 PH meter (Thermo scientific, Hemel Hempstead, UK) and then replaced by fresh media for the next day point. Culture media alone was used as control for the whole time course.

\section{Cell Culture Studies}

Both human osteoblast-like osteosarcoma cell line (MG63, European Collection of Cell Cultures, Porton Down, UK) and human mesenchymal stem cells (hMSCs) (passage 3) were used for cell studies in which they were incubated in standard conditions $\left(37^{\circ} \mathrm{C}, 95 \%\right.$ air, $5 \% \mathrm{CO}_{2}, 95 \%$ relative humidity) in Dulbecco's modified Eagle medium (DMEM, Gibco, Life Technologies, Paisley, UK). MG63 cells were selected as they have been commonly used to establish the preliminary aspects of biocompatibility for a wide range of phosphate glasses, whereas hMSCs are considered the gold standard for such studies. By the time of reaching $80 \%$ confluence, cells were trypisinzed to allow seeding onto glass beads. The glass beads were sterilised by immersion in ethanol then dry heat at $180^{\circ} \mathrm{C}$ for 1 hour.

The seeding procedure was similar for both cell types which was performed firstly by coating $100 \mathrm{mg}$ of glass beads with bovine fibronectin in PBS $\left(10 \mathrm{ug} \cdot \mathrm{mL}^{-1}\right)$ for one hour to aid initial cell attachment and then these glass beads were placed in a 24 ultralow attachment well plate (Corning, USA) in which the plate bottom surface was covered with beads completely. Later on, these glass beads were incubated in culture media overnight at $37^{\circ} \mathrm{C}$. The next day, the culture media was taken out and cell seeding was performed on the glass beads according to the preferred seeding density in which 
cells were left for 30 minutes in an incubator to allow cell attachment. After that the glass beads were transferred into $6.5 \mathrm{~mm}$ inserts in 24 well plates.

Two types of culture media were used, (1) Dulbecco's modified Eagle medium (Gibco, Life Technologies, Paisley, UK) supplemented with 10\% fetal bovine serum (Gibco) and 1\% penicillin/streptomycin (PAA Laboratories, GE Healthcare, Chalfont St. Giles, UK) that was used for the MG63 cells study, while (2) osteogenic medium (OM) for hMSCs studies and was prepared as the previous work (18) by using low glucose Dulbecco's modified eagle medium (DMEM), supplemented with fetal bovine serum , penicillin/streptomycin $1 \%$, dexamethasone $(0.1 \mu \mathrm{M})$, ascorbic acid 2-phosphate $(0.2$ $\mathrm{mM})$, and glycerol 2-phosphate $(10 \mathrm{mM}$; last three chemicals procured from SigmaAldrich, UK). Both of these culture media were replaced by half every 3 days. Commercial silica based glass microspheres (Polyscience Inc., USA) were used as a control for all the cell culture studies.

\section{CCK assay}

Following the seeding of MG63 cells at a density of 3000 cells per trans-well insert in 24 well plates, the 24 well tissue culture test plate was left in a $37^{\circ} \mathrm{C} / 5 \% \mathrm{CO}_{2}$ incubator for 1, 4 and 7 days. In parallel, cells were seeded in a second test plate at different densities for calibration. At each time point, CCK8 (Cell Counting Kit 8, Sigma-Aldrich) was added to each well in a $10 \%$ proportion of the culture media then incubated for 3 hours. Afterwards, fluorescence measurement was performed for each well plate in triplicate by using a plate reader (Infinite ${ }^{\circledR}$ M200, Tecan) at $450 \mathrm{~nm}$ wavelengths.

\section{Alkaline phosphatase Assay}

hMSCs were used for this assay, which were seeded at a density of 25000 cells per trans-well insert and incubated at $37^{\circ} \mathrm{C} / 5 \% \mathrm{CO}_{2}$ for 7 and 14 days. Subsequent dilutions of ALP standard reagent were performed for calibration. In all time points, the culture media was removed following the company protocol (Alkaline Phosphatase Assay, SensoLyte ${ }^{\circledR}$ pNPP) followed by cells washing with $1 \mathrm{X}$ assay buffer and cells permeabilising by Triton X-100. Afterwards, the glass beads were pipetted vigorously for 1 minute to aid in cell permeabilisation, then cells were lysed further by two cycles of freeze-thaw cycles $\left(-20^{\circ} \mathrm{C}\right.$ for $20 \mathrm{~min}$, followed by $37^{\circ} \mathrm{C}$ for $\left.12 \mathrm{~min}\right)$ followed by 
subsequent centrifugation at $4^{\circ} \mathrm{C}$ for 10 minutes at $2500 \mathrm{rpm}$ Then, $50 \mu \mathrm{l}$ of the supernatant was added to $50 \mu l$ of pNPP in 96 well plate and kept for 4 hours in a $37^{\circ} \mathrm{C} / 5 \% \mathrm{CO}_{2}$ incubator. Finally, a stopping reagent was added into each well before taking triplicate fluorescence measurements of each transwell using a plate reader (Infinite ${ }^{\circledR}$ M200, Tecan) at $405 \mathrm{~nm}$ wavelengths.

\section{Ca assay}

Mesenchymal stem cells were used again for the Ca assay at a cell density of 25000 cell/ Trans-well and were incubated with the supplement of (OM) for 14 and 21 days. At each time point, the culture media was taken out and the glass beads were washed with phosphate buffered saline (PBS) three times then the cells were lysed by $1 \mathrm{M} \mathrm{HCl}$ and placed on a shaker for $\simeq 40$ minutes. After that, triplicates of $5 \mathrm{ul}$ of each trans well aliquot was transferred to 96 well plate and about 200ul of prepared Ca working agent was added to each triplicate then fluorescence measurement at wavelength $612 \mathrm{~nm}$ (Infinite ${ }^{\circledR}$ M200, Tecan) was performed. Various gradual dilutions of Ca standard $(100 \mathrm{uL}-0 \mathrm{uL})$ were made for calibration following the protocol (Quantichrom ${ }^{\mathrm{TM}}$, Calcium Assay Kit (DICA-500), Bioassay System). Other triplicates of $100 \mathrm{mg}$ of each composition were incubated alone without seeding cells to deduce the effect of glass composition on the final results.

\section{Cell imaging}

For MG63 SEM imaging was performed for each time point by removing the culture media then fixing cells initially in 3\% glutaraldehyde followed by dehydration through graded ethanol $(50,70,90$, and $100 \%)$ then drying by hexamethyldisilazane (Aldrich, UK). While for hMSCs, imaging was done by fluorescence microscopy using phalloidin for cytoskeletal staining and propidium iodide for nucleus staining. The first step of this procedure was cell fixation in 3.7\% formaldehyde followed by cell permeabilization by using $0.5 \%$ triton $\mathrm{X}-100$ then finally cellular staining by both phalloidin (Alexa Fluor ${ }^{\circledR} 488$ Phalloidin, Sigma-Aldrich Gillingham, UK) and 4ug/ $\mathrm{mL}$ propidium iodide ( Propidium iodide, Sigma-Aldrich Gillingham, UK).

\section{$\underline{\text { Statistical analysis }}$}


Cell data for both cell counting and metabolic activity measurements were statistically assessed by Kruskal-Wallis where $p<0.05$ has been used as a significance degree estimation.

\section{$\underline{\underline{\text { Results }}}$}

\section{$\underline{\text { XRD }}$}

XRD spectra of the glasses showed a broad peak at $2 \theta$ values of $\simeq 20-40^{\circ}$. This emphasized the all the prepared glass samples were amorphous and were free crystallinity as shown in figure 1.

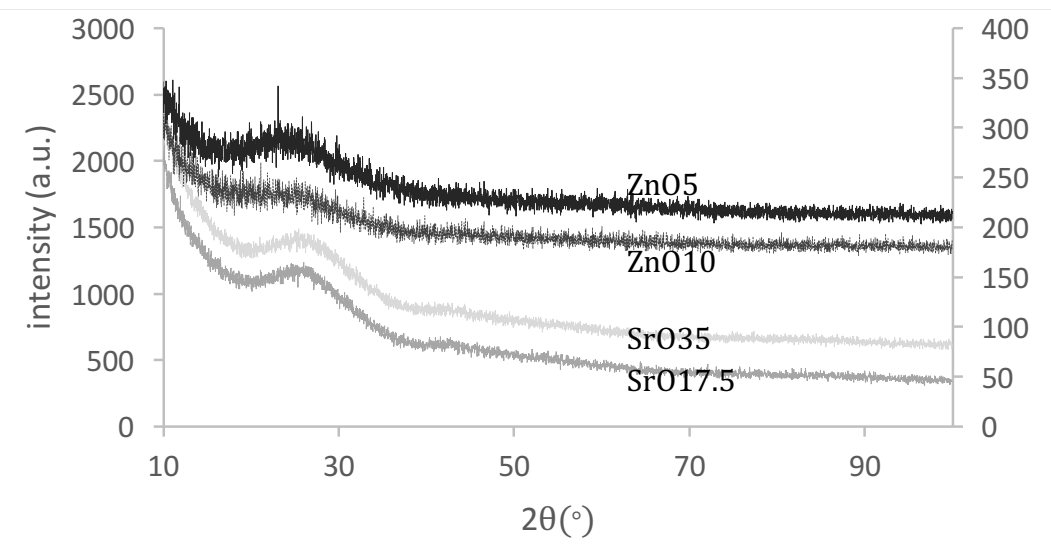

Figure1: XRD spectrum for glass

\section{Glass beads distribution}

The assessment of the different SEM images of the beads showed that the majority of glass beads produced were between 63um-106um; therefore, these sizes were used for the subsequent studies. Figure 2 demonstrates this as well as the picture of glass beads under SEM . 


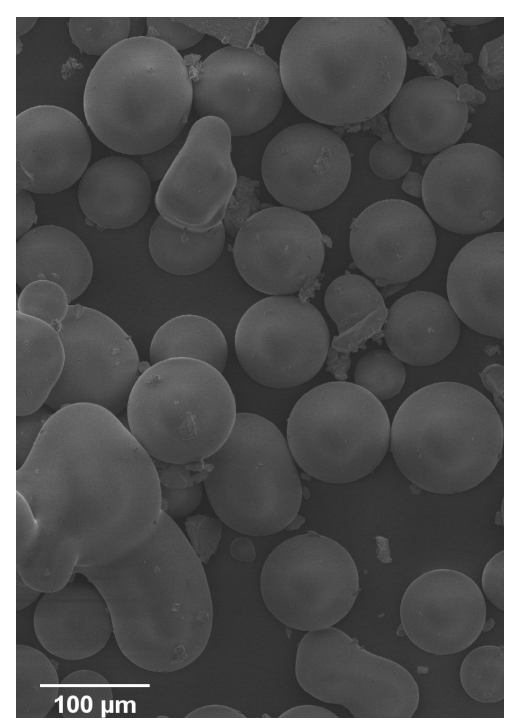

A

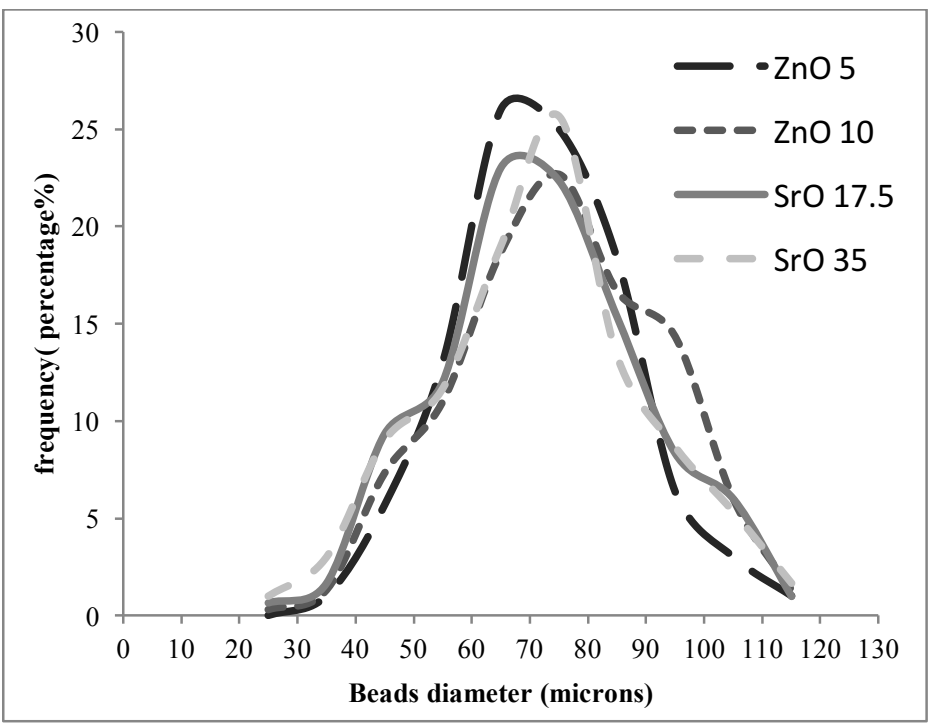

B

Figure (2): A-SEM picture of glass beads B- frequency distribution of glass beads

\section{Mass loss}

As shown in (figure 3), the images taken to visualise the glass bead surface changes showed that the amount of surface changes increased with time. These changes were at their highest range on day 14 after immersion in deionized water in comparison with images from the previous days beads immersion samples. Regarding day 1 , there were no clear surface changes in comparison with day 0 . On day 7 , there was a clear difference and prominent wear on the glass beads surface in the zinc oxide groups which revealed groups of pits formed while strontium oxide glass showed lower levels of changes than the zinc oxide groups with the least change seen with SrO17.5. However, on day 14 the glass degradation increased clearly with an increase in pits and the presence of small cracks in the zinc oxide glass with the presence of more surface wear in $\mathrm{SrO} 35$ and small pits in $\mathrm{SrO} 17.5$. These results showed that the $\mathrm{ZnO} 10$ glass was the most vulnerable to surface changes followed by $\mathrm{ZnO} 5$ then $\mathrm{SrO} 35$ and finally SrO17.5, which revealed the lowest level of surface changes. 
$\mathrm{ZnO5}$
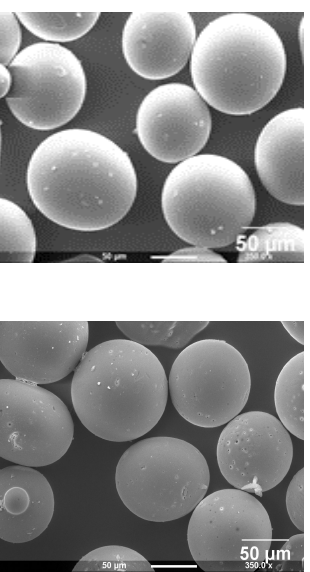

Day 1

Day 7
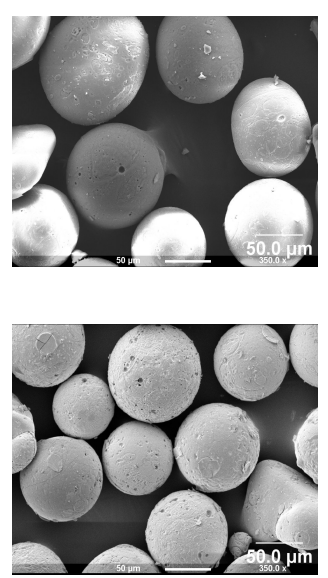

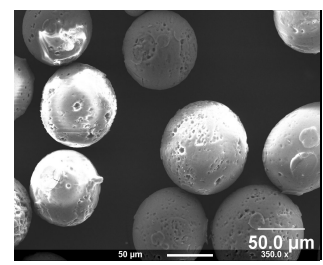

$\mathrm{ZnO} 10$
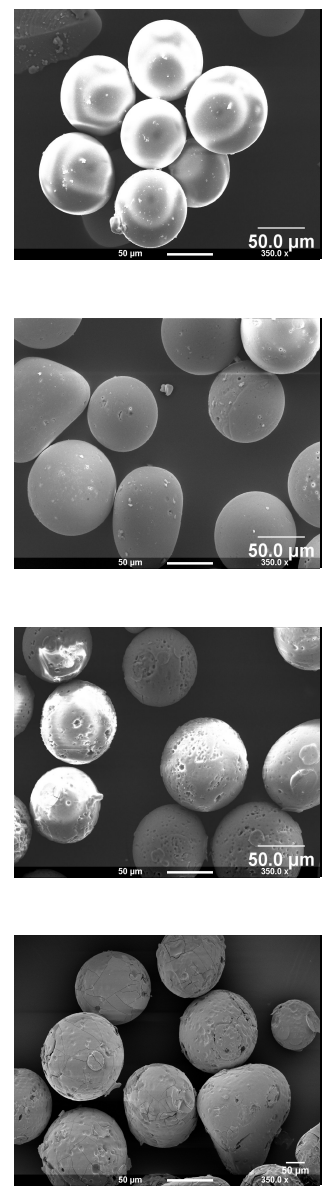
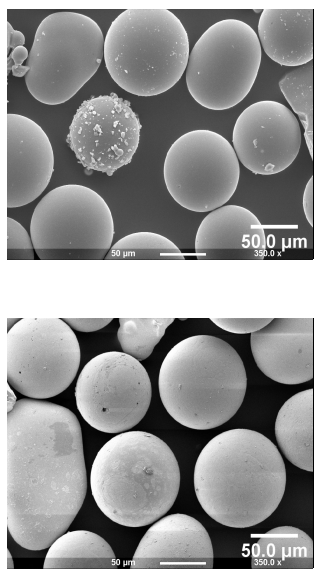

$\mathrm{SrO} 17.5$

$\mathrm{SrO} 35$
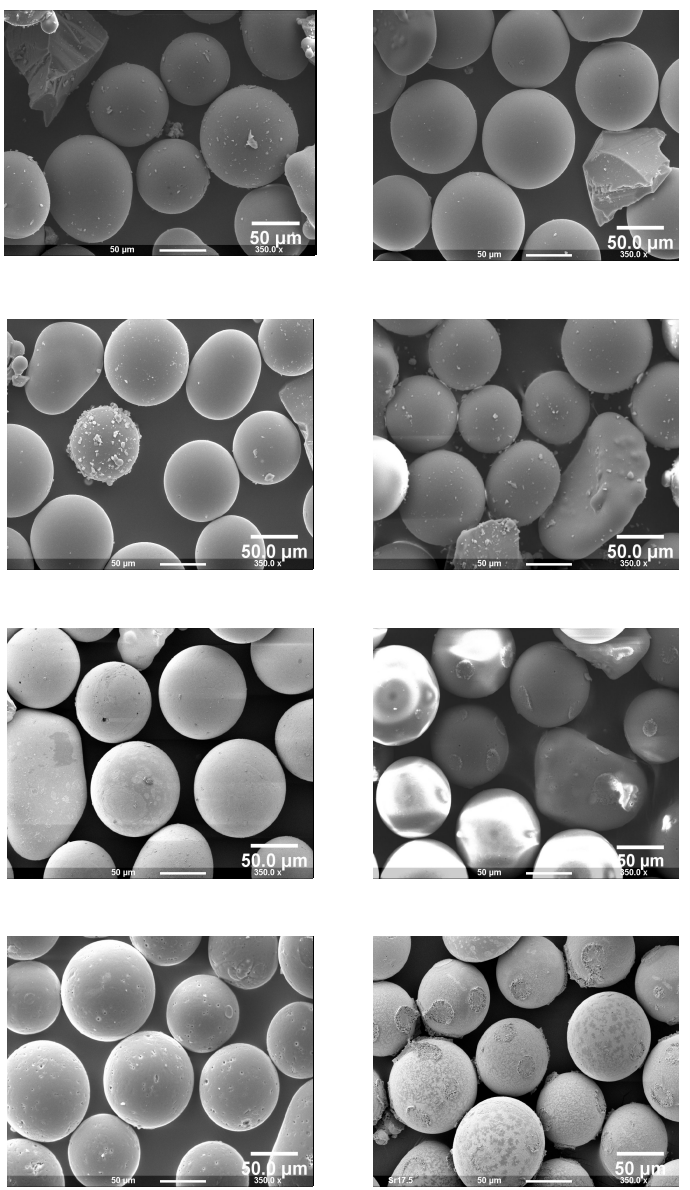

Figure 3: SEM pictures for glass beads after incubation in de ionized water showing the least degradation was with $\mathrm{ZnO} 10$ in day 14.

\section{Ion release}

Anion and cation release data revealed a gradual increase in the different ions released for all the compositions over the whole time frame. While the trend of ion release for the anions $\left(\mathrm{P}_{2} \mathrm{O}_{7}{ }^{4-}, \mathrm{P}_{3} \mathrm{O}_{9}{ }^{4-}, \mathrm{P}_{3} \mathrm{O}_{10}{ }^{5-}\right)$ was $(\mathrm{ZnO} 10>\mathrm{ZnO} 5>\mathrm{SrO} 17.5>\mathrm{SrO} 35)$, it was for $\mathrm{PO}_{4}{ }^{3-}$ as $(\mathrm{ZnO} 5>\mathrm{ZnO} 10>\mathrm{SrO} 17.5>\mathrm{SrO} 35)$. For all anions, SrO35 glass release of anions was significantly lower compared to the other compositions. Over the whole study, the anion release for both zinc containing glass compositions were close to each other and were significantly higher in comparison to the ion release for the strontium containing glasses (figure4). 
Similarly, the cation release showed the same trend as the anions in which the zinc based glass showed higher release of $\mathrm{Na}^{+}$and $\mathrm{Ca}^{2+}$ compared to the strontium based glasses. $\mathrm{ZnO} 5$ showed the maximum release of both $\mathrm{Na}^{+}$and $\mathrm{Ca}^{2+} ; 106-\mathrm{ppm}$ and 92ppm respectively, which was double the value of SrO17.5. The latter was followed by SrO35 with the lowest level of release with less than $10 \mathrm{ppm}$ for $\mathrm{Na}^{+}$and lower than 5 ppm for $\mathrm{Ca}^{2+}$ (figure $5 \mathrm{a} \& \mathrm{~b}$ ).

Concerning zinc ion release, $\mathrm{ZnO10}$ exhibited more $\mathrm{Zn}^{+2}$ ion release than $\mathrm{ZnO}$. Despite $\mathrm{Zn}^{+}$ions release was quite similar on day 1 at about 35 ppm, ZnO10 glass clearly released more $\mathrm{Zn}^{+}$ions over the time points after day 1 to stand at around 385 ppm after two weeks that was about $100 \mathrm{ppm} / \mathrm{mg}$ more than that of $\mathrm{ZnO} 5$ which ended at $280 \mathrm{ppm}$ on the same day point (figure $5 \mathrm{c}$ ).

$\mathrm{Sr}^{2+}$ ion release was around $3 \mathrm{ppm}$ for both $\mathrm{SrO} 17.5$ and SrO35 on day 1. As the study continued for the next time points, $\mathrm{SrO} 35$ tended to release more $\mathrm{Sr}^{2+}$ ion than that of SrO17.5 A linear trend was seen, to end around 33 ppm on day 14 which was significantly higher than that of SrO17.5 at around 25 ppm (figure $5 \mathrm{~d}$ ).
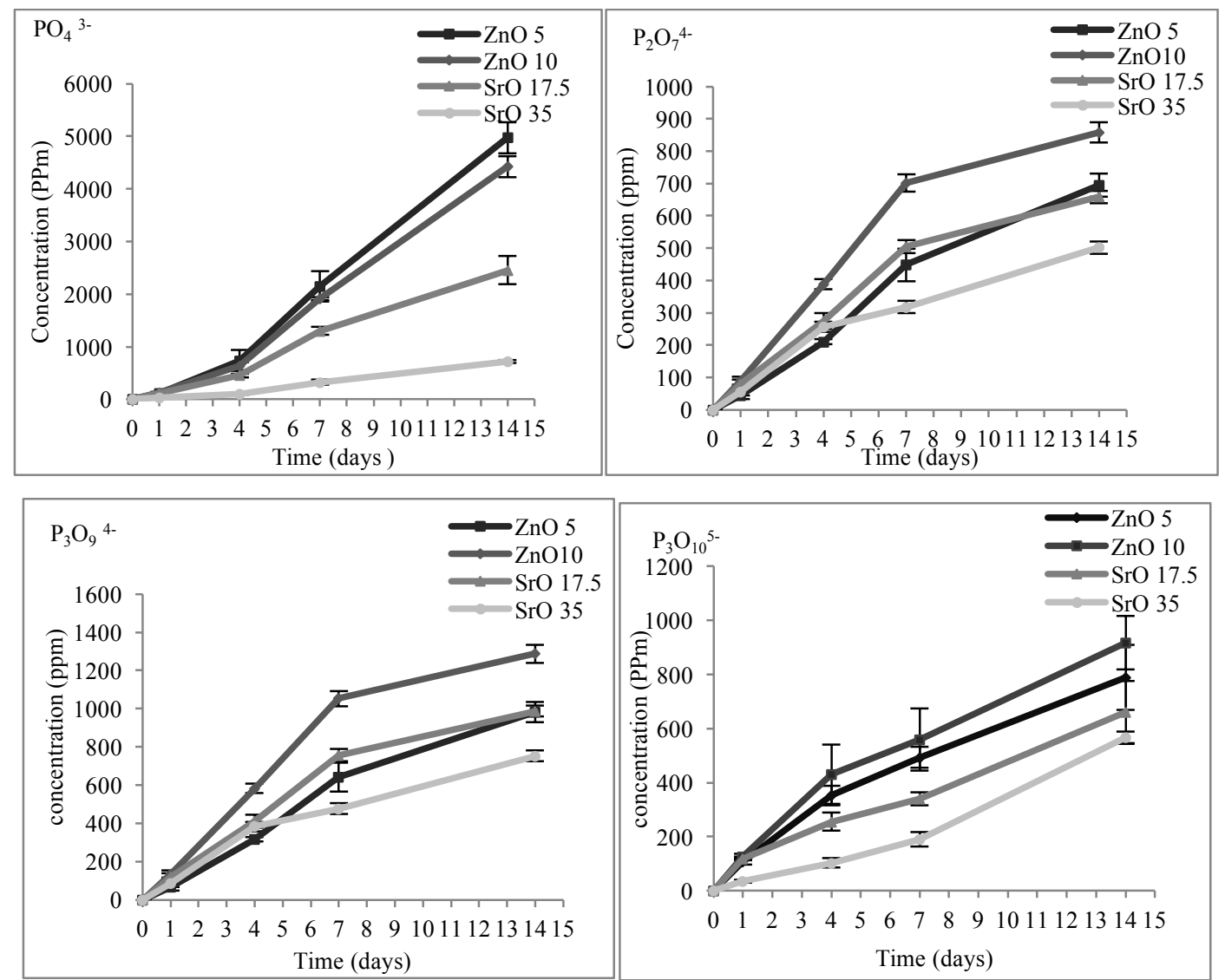
Figure4: Anion release showing higher release of phosphates ions $\left(\mathrm{PO}_{4}{ }^{3-}, \mathrm{P}_{2} \mathrm{O}_{7}{ }^{4-}\right.$,

$\left.\mathrm{P}_{3} \mathrm{O}_{9}{ }^{4-}, \mathrm{P}_{3} \mathrm{O}_{10}{ }^{5-}\right)$ by zinc based glass in comparison to strontium glass.
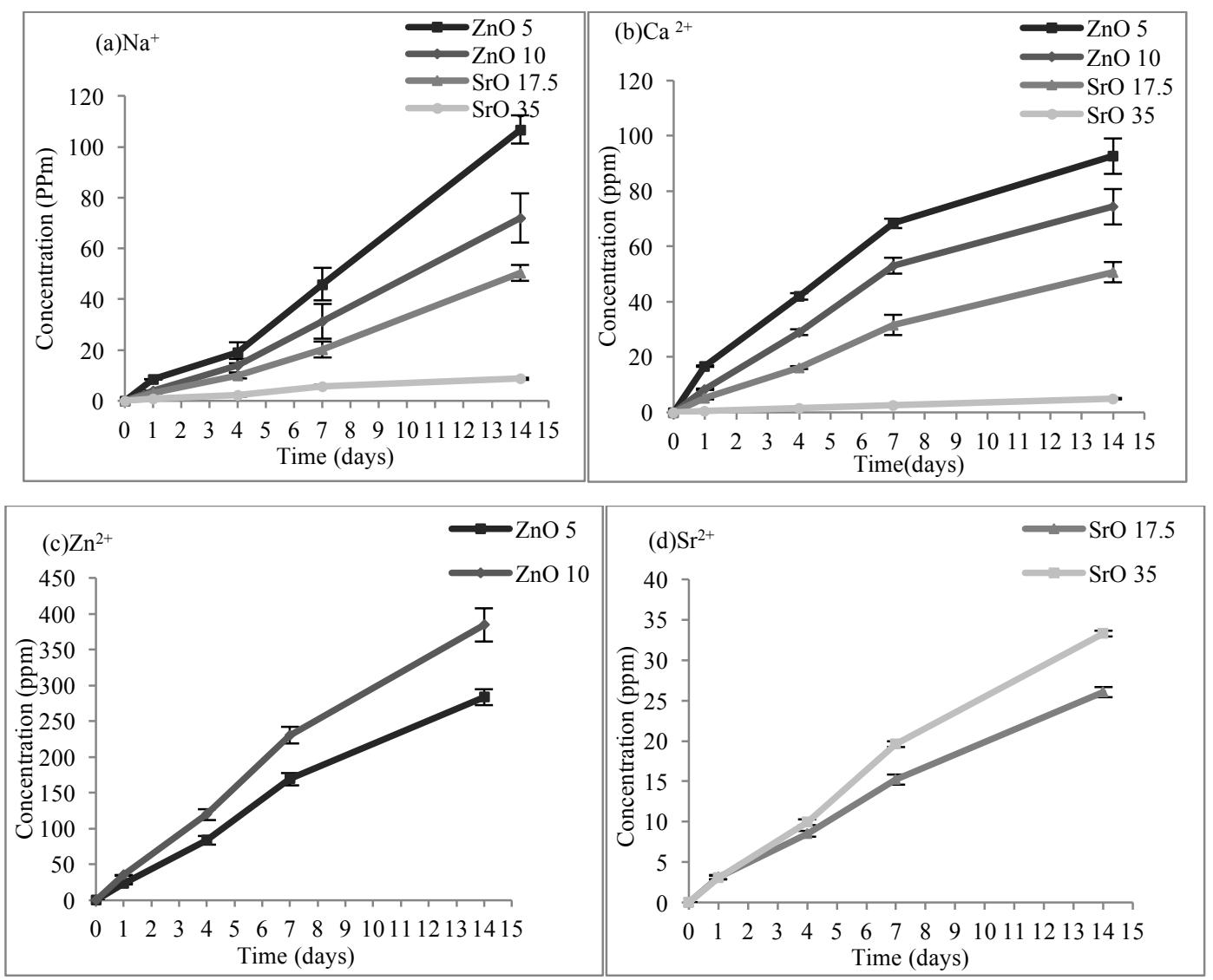

Figure 5: Cation release (a) $\mathrm{Na}^{+}$release, (b) $\mathrm{Ca}^{2+}$ release, (c) $\mathrm{Zn}^{+}$release (d) $\mathrm{Sr}^{2+}$ release

\section{pH Measurement}

$\mathrm{pH}$ data revealed a significant variation in $\mathrm{pH}$ level over the time course of the study. $\mathrm{pH}$ readings were around 8.7 at the beginning of the study, however, it rose on day 1 to reach around 9.2-9.3 for all groups. This rise was sustained at the same level until day 4 of which a slight decline was noticed for all the other time points in comparison to the control, which remained stable for the whole experiment period except for the $\mathrm{ZnO10}$. Surprisingly, ZnO10 decreased significantly after day 4 and showed the lowest $\mathrm{pH}$ level for the whole period until the end of the study finishing just slightly higher than 8.2. These results were demonstrated in figure 6 . 


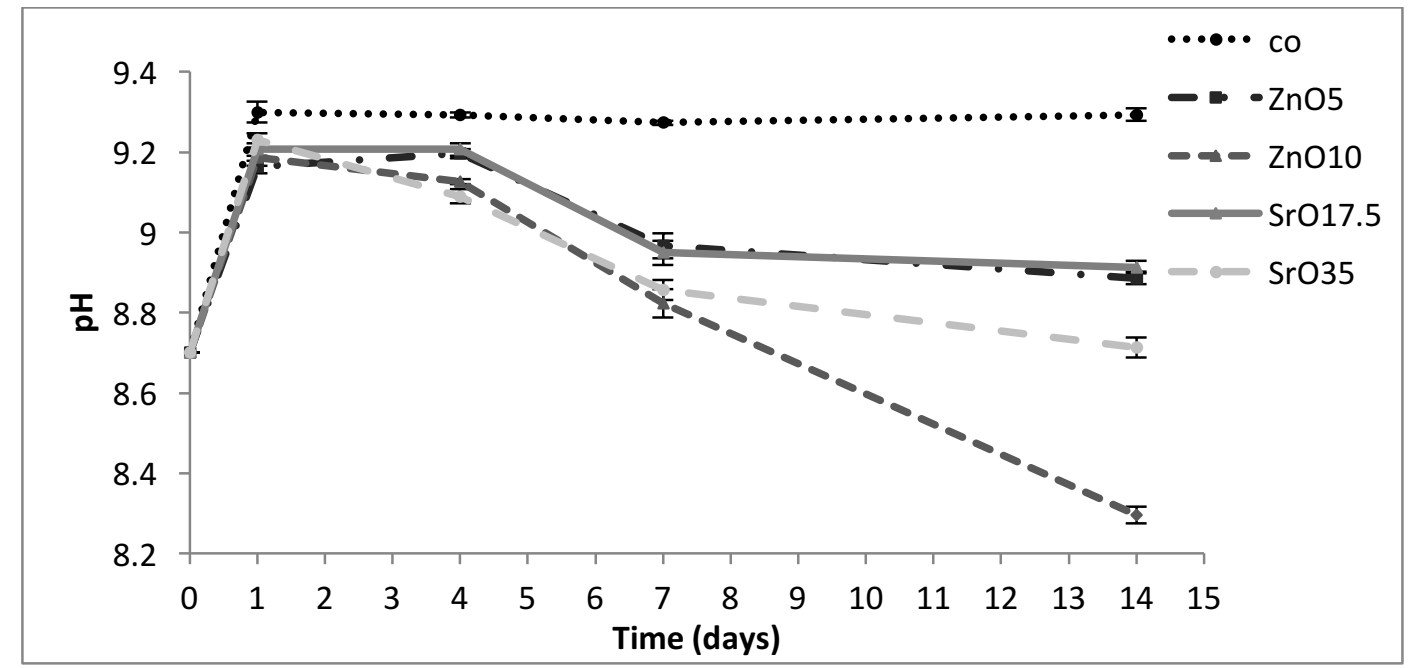

Figure 6: $\mathrm{pH}$ level showing that $\mathrm{ZnO} 10$ was with the least $\mathrm{pH}$ level in comparison to the control which remained steady.

\section{Cell Assays}

\section{1- CCK Measurement}

CCK data revealed that the number of cells increased gradually over time. Initially cells were seeded as 3000 cells per trans-well. This number had reached 13000 cells on day 1 for $\mathrm{ZnO} 5$ and SrO17.5. The former was with insignificantly higher than control and ahead of both $\mathrm{ZnO} 10$ and $\mathrm{SrO} 35$ at around 7000 cells. On day 4, cells number in both $\mathrm{ZnO} 5$ and $\mathrm{SrO} 17.5$ were around 34000 cells. This was significantly lower in comparison to the control that was about 38000 cells. At the last time point, cellular growth continued to increase and ended at around 40000 cells for $\mathrm{ZnO} 5$ and $\mathrm{SrO} 17.5$, which was about 5000 less than that of the control.

In general, $\mathrm{SrO} 35$ and $\mathrm{ZnO} 10$ showed the lowest cell numbers for all three times points. Whereas SrO17.5 and $\mathrm{ZnO} 5$ displayed more promising results in the same time frame. Figure 7 shows the biocompatibility of different compositions in compare to control in different time points. 


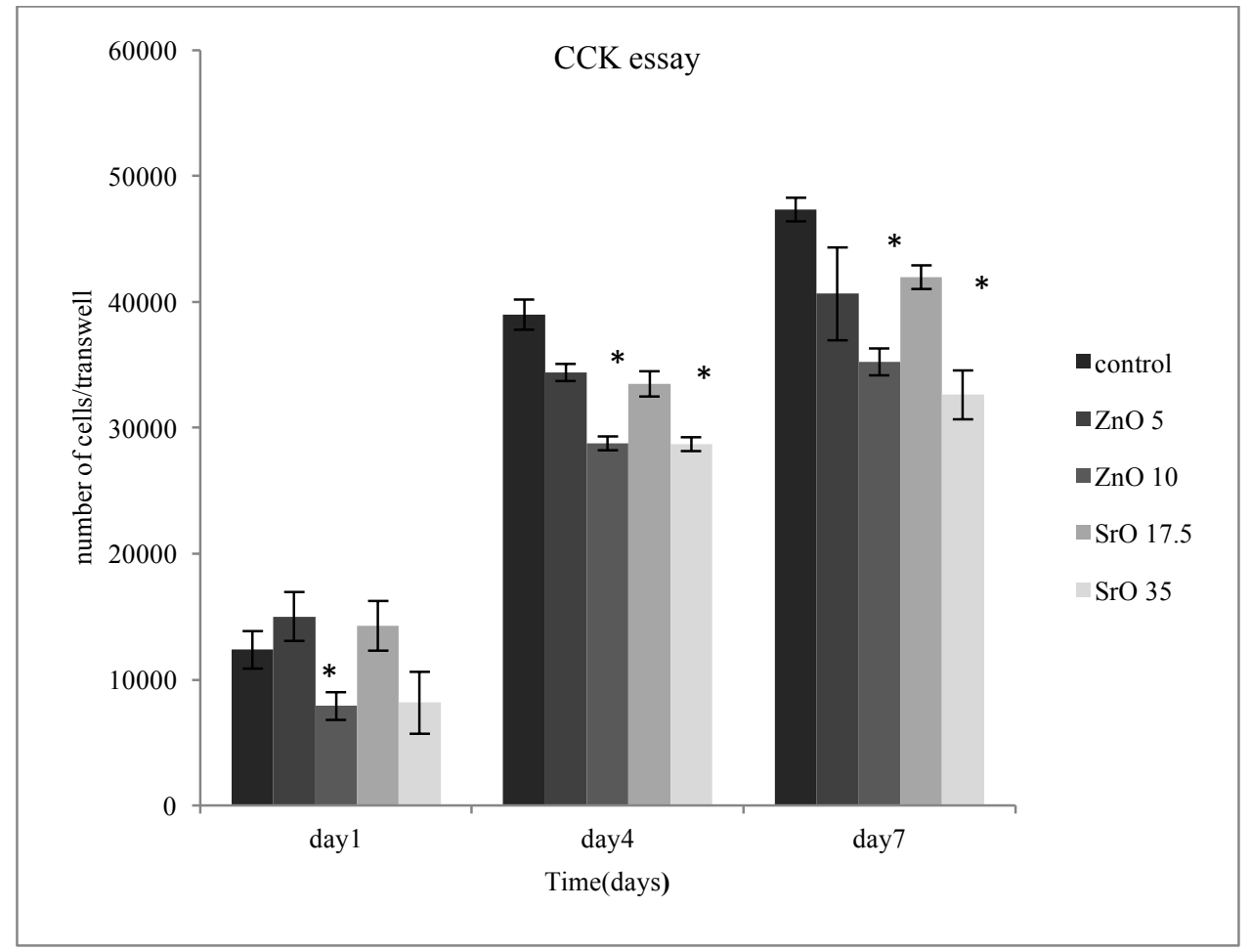

Figure 7: CCK assay for MG63 cells showing that both $\mathrm{ZnO} 5$ and $\mathrm{SrO} 17.5$ have good biocompatibility in comparison with the control. $\mathrm{ZnO} 5$ and $\mathrm{SrO} 35$ displayed less

\section{2-Alkaline phosphatase Measurement:}

Figure 8 summarises the alkaline phosphatase results after one and two weeks. At day 7, all compositions showed an enzyme concentration that was similar to the control (6.5ug/trans-well) except $\mathrm{ZnO} 5$ and $\mathrm{SrO} 35$ which were statistically slightly higher than control. On day 14, there was an increase in enzyme levels for all prepared glass types with the highest levels being shown for glasses $\mathrm{ZnO} 5$ and $\mathrm{SrO} 17.5$ (17.5ug/trans-well). This was slightly less than the control (20ug/ trans-well). SrO35 displayed the lowest enzyme levels (13ug/ trans-well). 


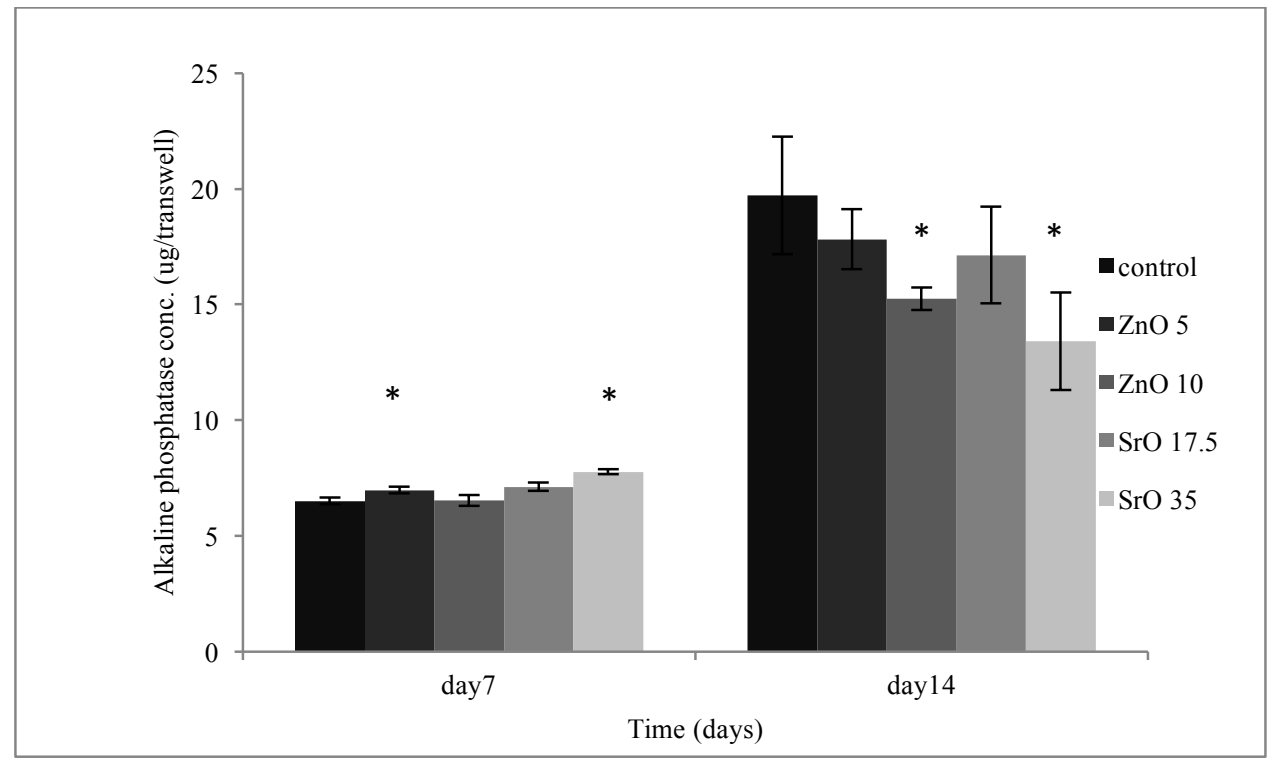

Figure 8: Alkaline phosphatase for hMSCs measured by ug/ trans-well, displaying an acceptable enzyme activity in $\mathrm{ZnO} 5$ and $\mathrm{SrO} 17.5$ in relation to the control.

\section{3-Mineralization Measurement (Ca assay)}

Figure 9 displays the $\mathrm{Ca}$ assay for day 14 and 21 . At the first time point all glass compositions seemed to stimulate cells to produce calcium at levels higher than that of control. $\mathrm{ZnO} 5$ and $\mathrm{SrO} 17.5$ values were higher than that of $\mathrm{ZnO} 10$ and $\mathrm{SrO} 35$ while the control showed the lowest concentration $(2 \mathrm{ug} /$ trans-well). Although the control data showed a 4-fold increase on day 21 in compare to day 14, it showed the lowest concentration compared to the zinc and strontium-based glasses. ZnO5 and Sr17.5 results were highly significant $(28 \mathrm{ug} /$ transwell) than the other compositions and the control. 


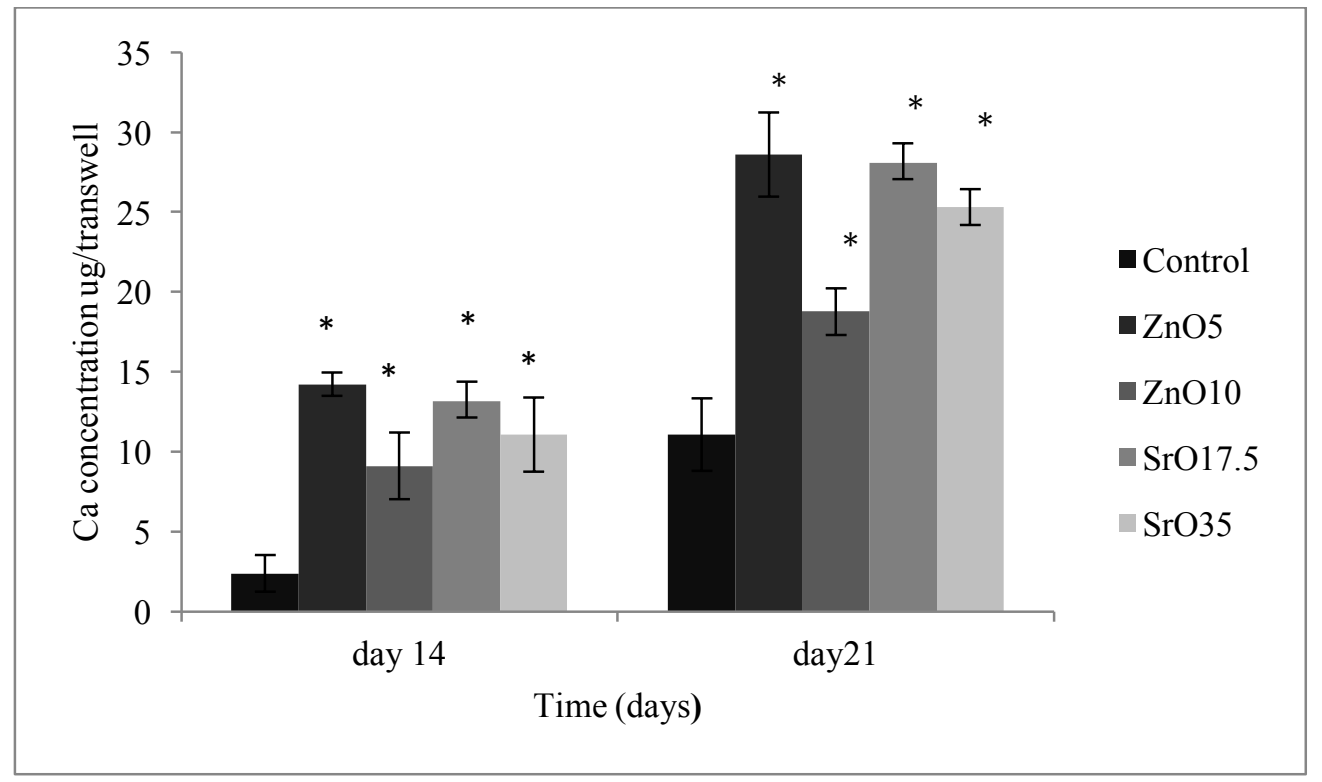

Figure 9: Ca concentration for hMSCs measured by ug/ transwell for day 14 and 21, revealing that $\mathrm{ZnO} 5$ and $\mathrm{SrO} 17.5$ have the highest calcium concentration.

\section{$\underline{4-\text { Cell imaging }}$}

SEM pictures of MG63 showed the ability of the cells to attach to the glass beads. Figure 10a displays the attachment of cells on strontium based glass day on day 1, while figure $10 \mathrm{~b}$ shows the ability of MG63 to proliferate trying to make a continuous layer of cells among the beads on day 7 .
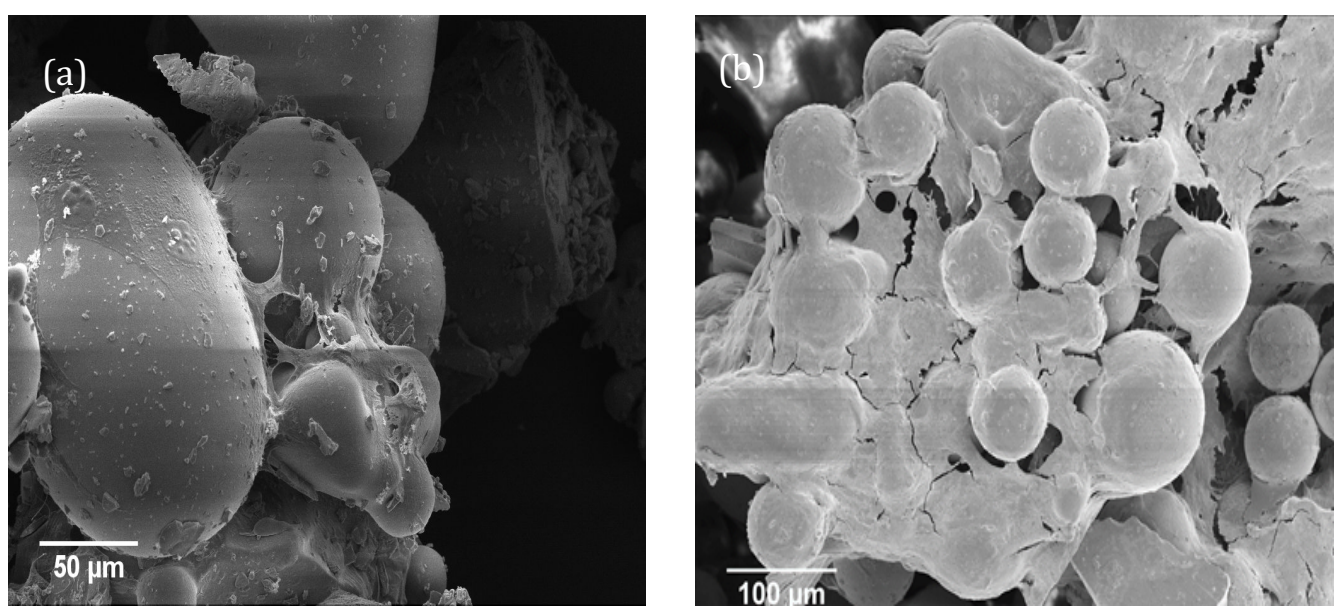

Figure 10: SEM pictures of MG63 on SrO17.5 strontium glass beads. a- day1, b- day7

Similarly, confocal images for hMSCs showed that these cells could attach to the beads and even encapsulate these beads and take on their spherical morphology as shown in figure 11 . 

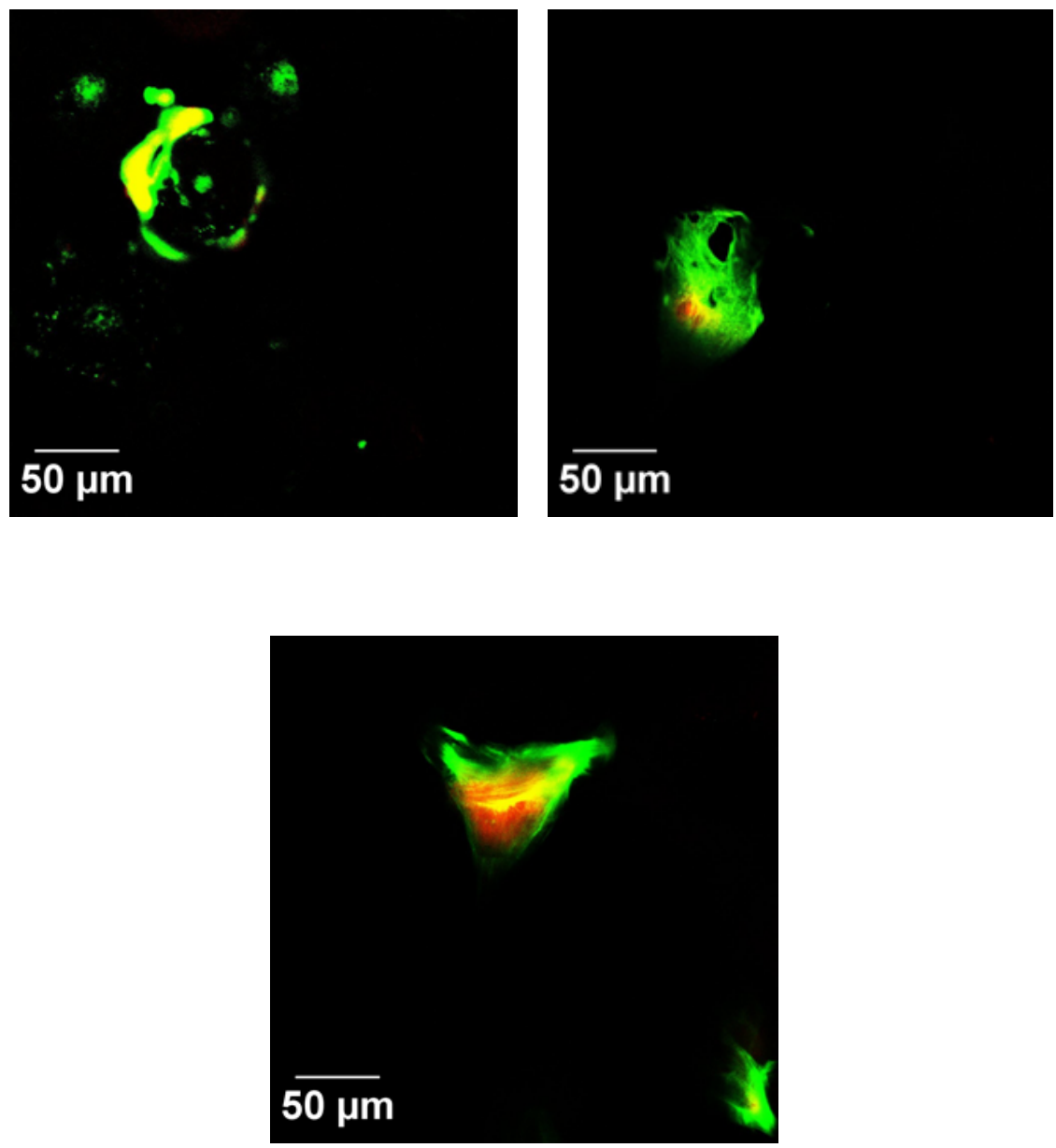

Figure 11: Confocal images of hMSCs showing the cellular attachment on beads 


\section{Discussion :}

The aim of this study was to determine the role of zinc and strontium in phosphatebased glasses for hard tissue (bone) engineering application. According to previous studies, calcium, zinc and strontium were proven to play a pivotal role in bone growth and development (19-22). Various earlier studies were carried out within our department assessing different properties of zinc and strontium phosphate glass. These studies were performed by preparing different phosphate glass compositions that are $\left(\mathrm{P}_{2} \mathrm{O}_{5}-\mathrm{Na}_{2} \mathrm{O}-\mathrm{CaO}-\mathrm{TiO}_{2}-(\mathrm{ZnO}\right.$ or $\mathrm{SrO})$ based and showed that $\mathrm{ZnO}$, $\mathrm{ZnO} 10, \mathrm{SrO} 17.5$ and $\mathrm{SrO} 35$ had an acceptable physical, chemical and biological properties (16). This was the main reason of this present study to focus on such glass compositions. Furthermore, the other aim was to develop the glass in a form that may be more accessible for cells to penetrate and colonise inside it rather than the use of glass discs as performed in the previous studies. Hence, phosphate glasses in this study were produced in the form of beads by using a spheriodisation method (8).

Qualitative assessment of bead degradation by imaging was adopted due to the difficulty and unreliability of making quantitative mass loss measurements. The images obtained gave us a general idea about the mechanical surface changes of glass beads after immersion in deionized water. These images showed that there were no major changes after day 1, however, as the incubation persisted for 1 week the erosion effect started to appear. This was more noticeable in both compositions of zinc based glasses and was in the form of pores and faint cracks which were more pronounced in $\mathrm{ZnO} 10$ phosphate glass in comparison to the less changed strontium compositions. Zinc phosphate glass was affected further on day 14 as more deep cracks started to appear with the formation of more pits. The strontium glasses, in turns, started to show few pits with few surface changes on day 14.

In general, $\mathrm{ZnO} 10$ tended to be the most susceptible to degradation followed by $\mathrm{ZnO} 5$ and $\mathrm{SrO} 35$ followed finally by SrO17.5. These results were concurrent with previous findings of mass loss trend. This can be explained by knowing that both zinc and strontium attach to phosphate glass network via ionic bonds with oxygen. The Zn-O

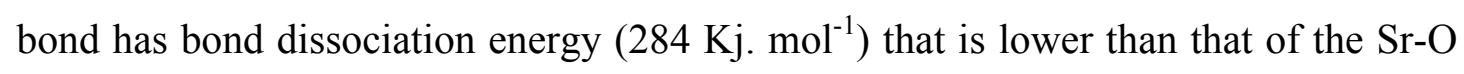
bond $\left(454 \mathrm{Kj} \cdot \mathrm{mol}^{-1}\right)$. This makes the zinc phosphate glass more vulnerable to hydrolysis as a result of its weaker bond strength. Moreover, our previous differential 
thermal analysis findings confirmed the current results via the thermal variables (Tg, $\mathrm{Tc}, \mathrm{Tm})$ which has followed the trend of $(\mathrm{ZnO} 10<\mathrm{ZnO} 5<\mathrm{SrO} 35<\mathrm{Sr} 17.5)(16,23)$.

The anion and cation release results for zinc phosphate glasses were concurrent with the mass degradation data in which higher levels of phosphate ions occurred with the more surface degraded glass. This can be explained by identifying the bond dissociation energies for both $\mathrm{CaO}$ and $\mathrm{ZnO} ; 383 \mathrm{Kj} \cdot \mathrm{mol}^{-1}$ and $284 \mathrm{Kj} . \mathrm{mol}^{-1}$ respectively. Consequently, when $\mathrm{ZnO}$ replace $\mathrm{CaO}$, there are higher numbers of weaker bonds, and hence more degradation and more ions are released. These results followed the pattern of previous data (17). Conversely, anion and cation release from the strontium containing samples did not follow the mass degradation pattern as the more degradable SrO 35 phosphate glass released fewer ions than that of $\mathrm{SrO}$ 17.5. These surprising results were actually similar to a previous study (16), the only exception was the $\mathrm{Sr}^{2+}$ ion release which was higher with $\mathrm{SrO} 35$ as it had double the amount of strontium than that of SrO17.5. Actually, this may give us a justification to interpret such unexpected results. Although SrO35 had more surface loss and higher degradation rate than SrO17.5, the majority of the released ions were $\mathrm{Sr}^{2+}$ which has a molecular weight of 87 more than other ions such as $\mathrm{Na}^{+}, \mathrm{Ca}^{2+}$ and $\mathrm{P}^{5-}$ that have molecular weight of 22,40 and 30 respectively.

Dulbecco Modified Eagles Medium (DMEM) with $\mathrm{pH} 8.4 \pm 0.1$ was used as an immersion liquid for glass beads in $\mathrm{pH}$ studies to mimic the same condition for cell culture studies. Data showed an irregular trend in which there was a rise on the first day then a period of stability followed by a slow decline of $\mathrm{pH}$ level. The control and all the compositions showed an initial increase in $\mathrm{pH}$ after one day which remained stable until day 4 as a result of gas absorption effects (24). This rise in $\mathrm{pH}$ was higher for the control group in comparison to the glass beads group. On day 7 , however, there was a gradual continuous decline in $\mathrm{pH}$ until day 14 for all glass beads. The control, however, remained at the same level for the rest of the study period. Surprisingly, $\mathrm{ZnO10}$ showed the lowest $\mathrm{pH}$ change followed by $\mathrm{SrO} 35$, which was slightly less than the other two groups. It appeared that the $\mathrm{pH}$ level was inversely related to the ion release, which was higher with $\mathrm{ZnO} 10$. This may be as a result of the increase of phosphate ions release that might form phosphoric acid in the solution and hence increase the culture media acidity. 
In general, cell culture studies displayed quite similar trends. In other words, the CCK results displayed that there was less metabolic activity in $\mathrm{ZnO} 10$ glass beads group than that in $\mathrm{ZnO} 5$ and $\mathrm{SrO} 17.5$ which were close to control. Furthermore, alkaline phosphatase for hMSCs acted similarly after 1 and 2 weeks as $\mathrm{ZnO} 5$ and SrO17.5 exhibited insignificant difference of enzyme levels from control. On the other hand, $\mathrm{Ca}$ assay demonstrated higher mineralisation rates in $\mathrm{ZnO} 5$ and $\mathrm{SrO} 17.5$ that were greater than remaining groups of $\mathrm{ZnO} 10$ and $\mathrm{SrO} 35$, control group had the lowest mineralization level.

Overall, cell studies gave an initial view about the role of zinc and strontium concentrations in phosphate glass and showed that $\mathrm{ZnO} 5$ and $\mathrm{SrO} 17.5$ phosphate glass beads have the most significantly positive effect on cells in compare to $\mathrm{ZnO} 10$ and SrO35. The interpretation of these result depends mainly on the relation between the released ions and their biological effect as shown by other studies (2). The current study measurements showed that the maximum released concentration of calcium and sodium among all glass compositions was about 95 ppm and 106 ppm respectively, which is below the cytotoxic concentration suggested in previous studies (i.e. for $\mathrm{Ca}^{2+}=400$ ppm, $\mathrm{Na}^{+}=220$ ppm $)(25,26)$. Consequently, the release of $\mathrm{Ca}^{2+}$ and $\mathrm{Na}^{+}$ions from these glass systems should not have any harmful impact on cell function. Although phosphate ions can play an important role in cell proliferation and metabolism, it was difficult to investigate their actual effect due to the presence of high phosphate contents ions in the medium thus they were not quantified in the medium. Regarding the strontium-containing glass beads, it was found that its $\mathrm{Sr}^{2+}$ release was about $30 \mathrm{ppm}$ and 25ppm for SrO35 and SrO17.5 respectively. In a previous study, the optimum concentration of $\mathrm{SrCl}_{2}$ to induce calcified matrix deposition was $5 \mathrm{ug} / \mathrm{ml}$, however, data showed that concentration of 10 to $20 \mathrm{ug} / \mathrm{ml}$ could also stimulate ALP and matrix deposition. There is a decline in the positive effect of $\mathrm{Sr}^{2+}$ ions as the concentration increase from 10 to $20 \mathrm{ug} / \mathrm{ml}$. Bearing this in mind, the actual $\mathrm{Sr}^{2+}$ ions concentration in the cell culture study is around half that of the data shown in the ion release results because of the frequent culture media change, so the real concentration of strontium in culture media is probably about $15 \mathrm{ppm}$ and $12.5 \mathrm{ppm}$ for $\mathrm{SrO} 35$ and $\mathrm{SrO} 17.5$ respectively. This was within an acceptable range and following the same pattern of cellular activity as discussed previously (27). Whereas for the zinc ion release, the current results confirmed previous findings that showed substitution of calcium with 
zinc by $10 \mathrm{~mol} \%$ can result in unfavorable and cytotoxic effects. Hence, adding more than $10 \mathrm{~mol} \% \mathrm{ZnO}$ may cause catastrophic effects as it can increase the release of lactate dehydrogenase and induce oxidative stress $(10,28)$.

\section{Conclusion}

The current study showed that glass beads were successfully produced in different compositions. It revealed also that $\mathrm{ZnO} 5$ and $\mathrm{SrO} 17.5$ phosphate glass beads exhibited better results regarding cellular studies that were significantly better than $\mathrm{ZnO} 10$ and SrO35 glass beads concluding that $\mathrm{ZnO} 5$ and SrO17.5 are more suitable for bone tissue engineering. These results could be further studied in future to assess their impact on bone tissue engineering aspects by performing other cell culture studies and use these types of phosphate glass as scaffold materials for bone repair. 


\section{Refrences}

1. Damien CJ, Parsons JR. Bone graft and bone graft substitutes: A review of current technology and applications. Journal of Applied Biomaterials. 1991;2(3):187-208.

2. Lakhkar NJ, Lee I-H, Kim H-W, Salih V, Wall IB, Knowles JC. Bone formation controlled by biologically relevant inorganic ions: Role and controlled delivery from phosphate-based glasses. Advanced Drug Delivery Reviews. 2013;65(4):405-20.

3. Uo M, Mizuno M, Kuboki Y, Makishima A, Watari F. Properties and cytotoxicity of water soluble $\mathrm{Na} 20-\mathrm{CaO}-\mathrm{P} 205$ glasses. Biomaterials. 1998;19(24):2277-84.

4. $\quad$ Ahmed I, Lewis M, Olsen I, Knowles JC. Phosphate glasses for tissue engineering: Part 1. Processing and characterisation of a ternary-based $\mathrm{P}(2) \mathrm{O}(5)-\mathrm{CaO}-\mathrm{Na}(2) \mathrm{O}$ glass system. Biomaterials. 2004;25(3):491-9.

5. Vitale-Brovarone C, Ciapetti G, Leonardi E, Baldini N, Bretcanu O, Verné E, et al. Resorbable Glass-Ceramic Phosphate-based Scaffolds for Bone Tissue Engineering: Synthesis, Properties, and In vitro Effects on Human Marrow Stromal Cells. Journal of biomaterials applications. 2010;26(4):465-89.

6. Bretcanu O, Baino F, Verné E, Vitale-Brovarone C. Novel resorbable glass-ceramic scaffolds for hard tissue engineering: From the parent phosphate glass to its bone-like macroporous derivatives. Journal of biomaterials applications. 2013;28(9):1287-303.

7. Navarro $M$, Ginebra M-P, Clément J, Salvador $M$, Gloria A, Planell JA. Physicochemical Degradation of Titania-Stabilized Soluble Phosphate Glasses for Medical Applications. Journal of the American Ceramic Society. 2003;86(8):1345-52.

8. Lakhkar NJ, Park J-H, Mordan NJ, Salih V, Wall IB, Kim H-W, et al. Titanium phosphate glass microspheres for bone tissue engineering. Acta Biomaterialia. 2012;8(11):4181-90.

9. Salih V, Patel A, Knowles JC. Zinc-containing phosphate-based glasses for tissue engineering. Biomedical Materials. 2007;2(1):11-20.

10. Abou Neel EA, O'Dell LA, Smith ME, Knowles JC. Processing, characterisation, and biocompatibility of zinc modified metaphosphate based glasses for biomedical applications. Journal of materials science Materials in medicine. 2008;19(4):1669-79.

11. Hamdy NA. Strontium ranelate improves bone microarchitecture in osteoporosis. Rheumatology (Oxford, England). 2009;48 Suppl 4:iv9-13.

12. Gentleman E, Fredholm YC, Jell G, Lotfibakhshaiesh N, O'Donnell MD, Hill RG, et al. The effects of strontium-substituted bioactive glasses on osteoblasts and osteoclasts in vitro. Biomaterials. 2010;31(14):3949-56.

13. Pan HB, Zhao XL, Zhang X, Zhang KB, Li LC, Li ZY, et al. Strontium borate glass: potential biomaterial for bone regeneration. Journal of the Royal Society Interface. 2010;7(48):1025-31.

14. Abou Neel EA, Chrzanowski W, Pickup DM, O'Dell LA, Mordan NJ, Newport RJ, et al. Structure and properties of strontium-doped phosphate-based glasses. 2008.

15. Lakhkar NJ, Abou Neel EA, Salih V, Knowles JC. Strontium oxide doped quaternary glasses: effect on structure, degradation and cytocompatibility. Journal of materials science Materials in medicine. 2009;20(6):1339-46.

16. Al Qaysi M, Walters NJ, Foroutan F, Owens GJ, Kim HW, Shah R, et al. Strontiumand calcium-containing, titanium-stabilised phosphate-based glasses with prolonged degradation for orthopaedic tissue engineering. Journal of biomaterials applications. 2015;30(3):300-10.

17. Qaysi MA, Petrie A, Shah R, Knowles JC. Degradation of zinc containing phosphatebased glass as a material for orthopedic tissue engineering. Journal of Materials Science: Materials in Medicine. 2016;27(10):1-11.

18. de Girolamo L, Sartori MF, Albisetti W, Brini AT. Osteogenic differentiation of human adipose-derived stem cells: comparison of two different inductive media. Journal of tissue engineering and regenerative medicine. 2007;1(2):154-7. 
19. Seo H-J, Cho Y-E, Kim T, Shin H-I, Kwun I-S. Zinc may increase bone formation through stimulating cell proliferation, alkaline phosphatase activity and collagen synthesis in osteoblastic MC3T3-E1 cells. Nutrition Research and Practice. 2010;4(5):356-61.

20. Yamaguchi M. Role of nutritional zinc in the prevention of osteoporosis. Molecular and cellular biochemistry. 2010;338(1-2):241-54.

21. Bose S, Fielding G, Tarafder S, Bandyopadhyay A. Understanding of dopantinduced osteogenesis and angiogenesis in calcium phosphate ceramics. Trends in biotechnology. 2013;31(10):594-605.

22. Romuald Mentaverri MB, Said Kamel and Patrice Fardellone. Potential AntiCatabolic and Anabolic Properties of Strontium Ranelate. Current Molecular Pharmacology. 2012;5(189-194).

23. Cottrell TL. The Strengths of Chemical Bonds. 2nd ed. London: Butterworth; 1958.

24. Brauer DS. Bioactive Glasses-Structure and Properties. Angewandte ChemieInternational Edition. 2015;54(14):4160-81.

25. Hallab NJ, Vermes C, Messina C, Roebuck KA, Glant TT, Jacobs JJ. Concentrationand composition-dependent effects of metal ions on human MG-63 osteoblasts. Journal of Biomedical Materials Research. 2002;60(3):420-33.

26. Maeno S, Niki Y, Matsumoto H, Morioka H, Yatabe T, Funayama A, et al. The effect of calcium ion concentration on osteoblast viability, proliferation and differentiation in monolayer and 3D culture. Biomaterials. 2005;26(23):4847-55.

27. Lopa S, Mercuri D, Colombini A, De Conti G, Segatti F, Zagra L, et al. Orthopedic bioactive implants: Hydrogel enrichment of macroporous titanium for the delivery of mesenchymal stem cells and strontium. Journal of biomedical materials research Part A. 2013;101(12):3396-403.

28. Aina V, Perardi A, Bergandi L, Malavasi G, Menabue L, Morterra C, et al. Cytotoxicity of zinc-containing bioactive glasses in contact with human osteoblasts. Chemico-Biological Interactions. 2007;167(3):207-18. 